\title{
Pengaruh Penggunaan Warna Terhadap Short Term Memory untuk Peningkatan Pemahaman Matematika
}

\author{
${ }^{1}$ Khufairotul Abidah, ${ }^{2}$ Adinda Azmi Laksmiwati, ${ }^{3}$ Yuni Sasfiranti, ${ }^{4}$ Ratna Supradewi \\ 1,2,3,4 Universitas Islam Sultan Agung, Semarang \\ 4ratnavina4@gmail.com
}

\begin{abstract}
Abstrak
Sebagian besar pelajar di Indonesia merasa bahwamatematika merupakan sesuatu yang sulit dipahami, membutuhkan ketelitian tinggi dan rumit. Banyak dari mereka yang harus melihat catatan berulang kali untuk dapat memahami konsep matematika yang diajarkan. Kinerja short-term memory sangat berperan penting dalam proses pemahaman suatu konsep secara menyeluruh. Warna memiliki berbagai fungsi psikologis yang berkaitan dengan system kognitif manusia, salah satunya yaitu meningkatkan kinerja memori. Penelitian ini bertujuan untuk mengetahui pengaruh penggunaan warna terhadap short-term memory untuk peningkatan pemahaman matematika. Populasi dalam penelitian ini merupakan siswa kelas 5 di SDIT Nurullman, Bangetayu, Semarang. Penelitian ini menggunakan pendekatan quasi eksperimen dengan desain post-test only with control group. Teknik pengambilan sampel yang digunakan yakni purposive sampling dan didapatkan masing-masing 26 siswa di kelompok eksperimen dan kelompok kontrol. Proses intervensi dilakukan dua kali dengan pemberian modul pembelajaran berwarna yang masing-masing berlangsung selama satu jam. Setelah pemberian pembelajaran dengan modul berwarna segera diberikan tes untuk diketahui nilainya sebagai representasi dari short-term memory. Berdasarkan hasil eksperimen yang dilakukan dengan desain post test only didapatakan nilai Sig. (2-tailed) > $0,05 y a k n i s e b e s a r$ 0,116, yang berarti tidak ada perbedaan antara kelompok eksperimen dan kelompok kontrol dalam perolehan nilai matematika. Dalam hal ini pemberian modul berwarna belum dapat meningkatkan short-term memory pada siswa SD.
\end{abstract}

Kata kunci : warna, short-term memory, pemahaman matematika

\section{Pendahuluan}

Matematika merupakan salah satu ilmu pengetahuan yang memiliki peran penting dalam kehidupan manusia. Konsep matematika dapat diterapkan secara luas dalam berbagai bidang kehidupan. Pembelajaran matematika di sekolah selalu diharapkan untuk bisa dikemas sedemikian rupa agar para siswa mampu 
PSISULA: Prosiding Berkala Psikologi

Vol. 1, 2019

E-ISSN: 2715-002X

memahami matematika secara optimal dan dapat menerapkannya dengan baik dalam kegiatan sehari-hari.

Pada tahun 2018 anak Indonesia dinyatakan gawat darurat matematika. Hasil penelitian RISE atau Research on Improvement of System Education pada tahun 2018 menunjukkan bahwa tidak terdapat perbedaan signifikan antara siswa baru masuk sekolah dasar di Indonesia dengan yang sudah tamat SMA dalam hal kemampuan memecahkan soal matematika sederhana. Studi Asesmen Kompetensi Siswa Indonesia yang dilakukan oleh Kemendikbud pada tahun 2016 juga memetakan bahwa sekitar $77,13 \%$ siswa SD di seluruh Indonesia memiliki kompetensi matematika yang berada dalam kategori sangat rendah dan hanya 2,29\% yang berada dalam kategori baik (Wahyuni, 2018). Dari data-data tersebut,dapat dilihat bahwa gawat darurat yang dimaksud adalah tidak berkembangnya kemampuan matematika siswa seiring bertambahnya tingkat sekolah yang diikuti dan penurunan yang terjadi dari tahun ke tahun.

Pemahaman merupakan kemampuan dalam menjelaskan suatu konsep, situasi atau tindakan. Pemahaman juga melibatkan adanya kemampuan untuk menerapkan dan menjelaskan kembali suatu konsep. Terdapat 5 indikator dari pemahaman matematika menurut Astuti (2013), yakni mampu menyatakan ulang konsep yang sudah dipelajari, mampu mengklasifikasikan objek-objek berdasarkan dipenuhi atau tidaknya persyaratan yang membentuk konsep tersebut. Mampu menerapkan konsep dalam penggunaan sehari-hari, dan mampu mengaitkan berbagai konsep matematika.

Pemahaman matematika dipengaruhi olehf aktor internal dan eksternal. Faktor internal meliputi sikap negatif dalam belajar matematika, motivasi belajar masih rendah, kesehatan tubuh tidak optimal, dan kemampuan pengindraan. Sedangkan faktor eksternal meliputi kurangnya variasi mengajar guru, penggunaan media pembelajaran yang belum maksimal, sarana prasarana di sekolah, serta lingkungan keluarga (Hasibuan, 2018). Motivasi belajar erat kaitannya dengan atensi. Atensi sendiri merupakan keseriusan, motivasi, perhatian dan fokus seseorang pada suatu hal. Bila fokus, maka perhatian akan lebih baik dan 
PSISULA: Prosiding Berkala Psikologi

Vol. 1, 2019

E-ISSN: 2715-002X

meningkatkan hasil belajar dan ingatan. Atensi seseorang akan meningkatkan kemampuan mengingat seseorang (Susanto, 2012). Semakin besar atensi seseorang maka motivasi akan naik dan meningkatkan daya ingat seseorang terhadap suatu fenomena (Palmer, 2004). Untuk dapat mengolah suatu informasi menjadi ingatan jangka panjang atau long-term memory, informasi tersebut harus diproses terlebih dahulu oleh memori jangka pendek atau short-term memory. Memori jangka pendek bertugas sebagai penyimpanan transitori yang menyimpan informasi secara terbatas kemudian mentransformasi dan menggunakan informasi tersebut dalam merespon suatu stimulus. Secara fungsi, memori ini bertugas untuk mengorganisasikan informasi, memberi makna informasi dan membentuk pengetahuan untuk disimpan di memori jangka panjang, sehingga kerap pula disebut memori pekerja. Dengan kata lain, memori jangka pendek mempunyai cukup kapasitas untuk memahami permasalahan. Terdapat sebuah ruang pada memori jangka pendek yang dapat digunakan untuk mengkonstruksi penyelesaian suatu permasalahan (Retnowati, 2008). Dari penjabaran tersebut, dapat disimpulkan bahwa pemahaman matematika juga memerlukan peran efektif dari memori jangka pendek.

Tidak sedikit yang berpendapat bahwa buku pelajaran yang kurang menarik turut mempengaruhi proses memahami materi yang dipelajari. Hal ini dapat dijelaskan dengan teori beban kognitif, yang menjelaskan Beban kognitif instrinsik ditentukan oleh tingkat kekompleksan informasi atau materi yang sedang dipelajari, sedangkan beban kognitif ekstrinsik ditentukan oleh teknik penyajian materi tersebut (Chandler \& Sweller, 1992). Teknik penyajian materi yang baik, yaitu yang tidak menyulitkan pemahaman, akan menurunkan beban kognitif ekstrinsik. Salah satu cara yang dapat dilakukan untuk meringankan beban kognitif ekstrinsik adalah dengan membuat modul pelajaran yang menarik.

Sebuah penelitian membuktikan bahwa penggunaan media kartu berwarna dapat membantu meningkatkan pemahaman siswa terhadap konsep bilangan bulat pada siswa kelas IV SD (Khoiriah, 2015). Warna juga terbukti dapat meningkatkan kinerja short-term memory dan dapat menjadi salah satu strategi alternative dalam 
PSISULA: Prosiding Berkala Psikologi

Vol. 1, 2019

E-ISSN: 2715-002X

penyajian materi untuk meningkatkan kemampuan kognitif dan hasil belajar siswa. Selain itu, apabila dikaitkan dengan teori perkembangan, anak-anak cenderung mengandalkan kemampuan visualnya dalam belajar atau mengobservasi lingkungan. Oleh karena itulah warna-warna yang terang dan mencolok akan lebih menarik perhatian anak-anak. Berdasarkan pemaparan tersebut, penelitian ini bertujuan untuk mengetahui pengaruh warna terhadap kinerja short-term memory dalam meningkatkan pemahaman matematika.

\section{Metode}

Penelitian ini terdiri dari dua variabel yaitu variabel bebas dan variabel tergantung. Variabel bebas dalam penelitian ini adalah penggunaan warna pada modul matematika dan variabel tergantung yaitu pemahaman matematika dalam bentuk skor nilai matematika. Penelitian ini menggunakan metode eksperimen dengan desain post-test only with control group, yaitu dilakukan pengukuran (posttest) sesudah pemberian treatment pada kedua kelompok. Partisipan dalam penelitian ini berjumlah 52 anak kelas 5 SD di SD Islam Terpadu Nurul Iman Semarang yang dibagi menjadi 2 kelas yaitu kelas B sebagai kelompok eksperimen dan kelas C sebagai kelompok control dengan cara purposive sampling. Setiap kelas memiliki jumlah siswa sebanyak 26 anak dengan rata-rata nilai UTS kelas B sebesar 56,15 dan kelas $C$ sebesar 55,19.

Dari data hasil uji normalitas nilai UTS Matematika pada kedua kelompok sebelum intervensi data terdistribusi normal dengan nilai K-Sz sebesar 0,443 dan Asymp. Sig (2-tailed) sebesar 0,989 dimana Sig. > 0,05. Selanjutnya dilakukan uji homogenitas pada pengukuran nilai UTS menghasilkan nilai levene statistic sebesar 0,668 dengan Sig. 0,418 dimana Sig. > 0,05 yang menunjukkan homogen. Berarti kelas B (kelompok eksperimen) dan kelas c (kelompok kontrol) setara/homogen.

Pada kelompok eksperimen diberi perlakuan, yaitu disajikan materi berupa modul matematika yang dicetak berwarna. Dalam hal ini materinya adalah pecahan dan pengolahan data. Sedangkan kelompok kontrol sebagai kelompok pembanding, 
PSISULA: Prosiding Berkala Psikologi

Vol. 1, 2019

E-ISSN: 2715-002X

disajikan materi berupa modul matematika yang dicetak hitam putih dengan materi yang sama. Setelah dilakukan intervensi selama 1 jam, siswa diberikan post-test berupa soal-soal mengenai materi yang telah diberikan. Hasil uji skor nilai matematika setelah dilakukan intervensi merupakan bentuk representasi shortterm memory subjek karena post-test itu sendiri langsung diadakan setelah pelaksanaan intervensi.

Kelompok eksperimen dan kelompok control juga diukur memorinya dengan menggunakan tes inteligensi yaitu digit span yang merupakan subtes dari alat tes WISC (Wechsler Intelligence Scale for Children). Berdasarkan uji homogenitas shortterm memory menghasilkan nilai levene statistic sebesar 0,886 dengan Sig. 0,351 dimana Sig. > 0,05 menandakan bahwa varians dari dua kelompok tersebut sama atau homogen.

\section{Hasil}

Data mengenai pemahaman matematika subjek diperoleh dari pengerjaan soal latihan mengenai materi modul yang telah diberikan, datanya berupa nilai skor matematika. Analisis data dalam penelitian ini menggunakan uji t antar kelompok dari program SPSS 20.0 for windows.

Berdasarkan hasil yang diperoleh uji independent t-test menunjukkan bahwa tidak ada perbedaan nilai matematika antara kelompok control dengan kelompok eksperimen, dimana T sebesar 1,1598 dengan nilai Sig. > 0,05 yakni sebesar 0,116 .

Tabel 1.

\begin{tabular}{ccccc}
\hline & $\mathrm{F}$ & $\mathrm{T}$ & Sign. (2 tailed) & Keterangan \\
\hline Post-test & 8,163 & 1,598 & 0,116 & Tidak Signifikan \\
\hline
\end{tabular}

Meskipun penelitian ini tidak terbukti, dari hasil observasi dan wawancara ternyata guru dan siswa lebih tertarik menggunakan modul yang berwarna. 
PSISULA: Prosiding Berkala Psikologi

Vol. 1, 2019

E-ISSN: 2715-002X

\section{Diskusi}

Data tersebut menunjukan bahwa hipotesis penelitian ditolak, artinya tidak ada pengaruh penggunaan warna terhadap pemahaman matematika siswa SD Islam Terpadu Nurul Iman Semarang. Dilihat dari tidak adanya perbedaan nilai post-test antar kelompok eksperimen dan kelompok kontrol. Nilai rata-rata kelompok eksperimen sebesar 69,9 dan kelompok kontrol 64,1.

Hal tersebut sesuai dengan pendapat Sedarmayanti (2009) yang mengungkapkan bahwa, selain berhubungan dengan daya ingat atau memori, warna disebut-sebut memiliki pengaruh yang besar terhadap perasaan. Sifat dan pengaruh warna kadang-kadang menimbulkan rasa senang, sedih dan lain-lain, karena dalam sifat warna dapat merangsang perasaan manusia. Manusia lebih mudah mengingat hal-hal yang berhubungan dengan emosi dan perasaan (Widodo, 2010) tetapi ada pula MF dari kelompok kontrol yang berpendapat bahwa baik berwarna atau hitam sama saja.

Penelitian Smilek, Dixon, dan Merikle pada tahun 2002 menghasilkan temuan performansi memori partisipan penelitiannya yang disajikan warna-warna kongruen lebih baik dibandingkan dengan warna hitam dan putih. Dalam pengaturan pendidikan, siswa diharapkan memiliki prestasi akademik yang sangat baik.

Sejauhmana siswa menggunakan kemampuan kognitifnya yang lebih baik (Mariam \& Intan, 2012). Kemampuan kognitif siswa mengacu pada cara siswa melihat, memperhatikan, mengingat, berpikir, dan memahami pelajaran. Perlu ada strategi untuk memfasilitasi proses belajar dan warna dapat memainkan peran dalam memotivasi siswa untuk belajar mereka.

Hasil penelitian ini menunjukkan tidak ada pengaruh modul berwarna dan modul hitam putih pada kelompok eksperimen dan kelompok kontrol. Hal ini dapat disebabkan oleh beberapa hal. Pertama, hasil post-test dapat dipengaruhi oleh efek pembelajaran sebelum intervensi. Beberapa materi yang dijadikan modul merupakan materi yang telah dipelajari sebelumnya, akan tetapi disampaikan lagi 
PSISULA: Prosiding Berkala Psikologi

Vol. 1, 2019

E-ISSN: 2715-002X

dan dimodifikasi menjadi modul berwarna atas pertimbangan wali kelas bahwa banyak siswa yang masih kesulitan memahami materi-materi tersebut, yakni pecahan. Selanjutnya adanya perbedaan cara penyampaian materi oleh pengajar di kelompok eksperimen dan kelompok control juga dapat mempengaruhi pemahaman matematika dan hasil post-test antar kelompok. Pemahaman matematika juga dipengaruhi oleh faktor internal atau faktor yang berasal dari dalam diri siswa, sedangkan modul yang menarik merupakan salah satu faktor eksternal yang mendukung peningkatan pemahaman matematika. Beberapa faktor internal yang dimaksud yakni motivasi belajar dan atensi masing-masing siswa. Seperti yang pernah dipaparkan oleh Todd \& Marois (2004), atensi seseorang akan meningkatkan kemampuan mengingat seseorang, yang mana dalam hal ini berkaitan erat dengan short term memory. Semakin besar atensi seseorang maka motivasi akan ikut naik dan meningkatkan daya ingat seseorang terhadap suatu fenomena (Palmer, 2004).

\section{Kesimpulan}

Berdasarkan hasil penelitian dan diskusi dapat disimpulkan bahwa tidak terdapat pengaruh penggunaan warna terhadap short term memory untuk peningkatkan pemahaman matematika pada siswa kelas 5 SD Islam Terpadu Nurul Iman Semarang. Materi berupa modul yang disajikan kepada kelompok eksperimen dengan bercetak warna dan kelompok kontrol bercetak hitam putih ternyata tidak memberikan pengaruh terhadap short term memory siswa yang dapat meningkatkan pemahaman matematika. Terbukti dari tidak adanya perbedan nilai yang signifikan post-test antara kelompok ekspermen dan kelompok kontrol. 
PSISULA: Prosiding Berkala Psikologi

Vol. 1, 2019

E-ISSN: 2715-002X

\section{Daftar Pustaka}

DePorter, B. \&. (2013). Quantum Learning. Bandung: Kaifa Learning.

Mariam A D, I. A. (2012). Students of low academic achievement-their personality, mental abilities and academic performance: How counsellor can help? Int J Hum SocScie, 220-225.

Palmer, J. (2004). Attentional limits on the perception and memory of visual information. Journal of Experimental Psychology: Human Perception and Performance, 16 (2), 332-350.

Radvansky, G. (2006). Memory. Boston: (MA): Pearson Education Group. Santrock, J. (2009). Psikologi Pendidikan. Jakarta: Salemba Humanika.

Smilek D, D. M. (2002). Research Report: Synesthetic color experiences influence memory. PsycholSci, 548-552.

Todd, J. J., \&Marois, R. (2004). Capacity limit of visual short-term memory in human posterior parietal cortex. Nature , 751-753.

Wichmann FA, S. L. (2002). The contributions of color to recognition memory for natural scenes. J ExpPsychol Learn, 509-520. 